\title{
日本語の「〜ている」と中国語の「〜着」について An Analysis of -teiru and -zhe
}

\section{方韻 \\ 香港中文大学}

\section{要旨}

日本語の「〜ている」と中国語の「〜着」は、意味と用法において類似している部分があるため、 従来関心度の高い研究対象になってきている。本稿では、主に動作の進行・持続、動作の繰り返 し・経験、単純状態、動作の方式という側面から、その両者の対照を行ってみた。総じていえば、 動作の進行と持続の用法において、「〜ている」と「〜着」には似ているところが多いが、表現機 能などの面では違いがみられる。動作の繰り返し、経験及び単純状態などの用法は、「〜ている」 にあるが、「〜着」には基本的にない。一方、動作の方式という用法になると、「〜着」にはみら れるが、「〜ている」には見あたらない。

キーワード :

動作の進行、持続、動作の繰り返し、状態、動作の方式 


\section{日本語の「〜ている」と中国語の「〜着」について}

\section{方韻}

香港中文大学

\section{1. はじめに}

日本語において、アスペクトといえば、まず「〜ている」の形が取りあげられる。一方、中国語 になると、そのアスペクトの機能は普通、アスペクト助詞といわれる「〜着」、「〜了」、「〜 过」によって果たされるが、この中で、「〜着」 ${ }^{1}$ が「〜ている」に近い表現としてよく議論されて きている（たとえば马，2010；郑・冯，2010など）。马（2010）は「〜ている」と「〜着」の対 応関係についてごく簡単に触れているが、見逃しているところが多い。例えば、結果継続の意味で はその両形式が対応していると马は主張しているが、日本語の「死んでいる」や「結婚している」 のような言い方は、中国語の「死着」や「结婚着」2のようには言い換えられない。ほかに、郑・冯 (2010) も「〜ている」と「〜着」の比較を取り上げているが、存在文にみられる結果持続の表現 に限定されているもので、経験や繰り返しなども意味する「〜ている」と「〜着」との対応関係の 有無などには言及していない。

これまでの研究には、以上のようにまだ十分に検討されていない点があると言わざるを得ない。 本稿では、そういう不足なところに注目し、より広い視野に立ってその両形式の対照分析を試みる。

\section{2.「〜ている」の意味用法の整理}

「〜ている」の意味用法についての研究は、内外ともに枚挙に暇がない。日本には吉川（1982）、 寺村（1984）、加藤・福地（1989）、庵（2005）などがあり、中国のほうには申・赵・王（1991）、 李（2009）などがあげられる。これらの研究をもとに「〜ている」の意味用法を以下にまとめる。

\section{1 動作の進行と持続}

「〜ている」の形の基本的な意味は、動作の進行と動作の持続 ${ }^{3}$ 表すことである。それぞれ以下 の例があげられる。

「〜着」は「〜 zhao」と発音され、結果補語として機能する用法があるが、アスペクトの表現 ではないため、それを本稿の範囲外とする。なお、本稿は主に動詞の後に用いられる「〜着」 を検討する。

「结着婚（呢）」の言い方は中国語にあるが、「式を挙げているところだ」のような意味合い で、「結婚している」のことではない。

本稿でいう動作の持続というものは、動作結果の持続（存続）という部分も含む。 
（1）ロサンゼルス空港に着いて市街の中心部にむかっているとき、感覚がにぶくなった。

(『アメリカ素描』p. 22)

（2）そんな唄を聴いていると、この十年間世界は何ひとつ変っていないんだという気がした。

（『羊をめぐる冒険（上）』p. 28)

（3）それに、女があの荷物には何がはいっているんだろうと珍らしそうに眺めたりすると、ちょっ と顔が赤くなるではないか。

(『掌の小説』p. 58)

（1）は動作の進行を、（2）と（3）は動作の持続と動作結果の持続をそれぞれ表す。「〜てい る」に込められているそういう意味の違いは、一般に継続動詞と瞬間動詞の違いによるものといわ れるが、実際その区別は微妙なところがある。例えば、「行く」は瞬間的動きではないが、「行っ ている」の「ている」は普通、動作結果の持続を表す。これについて、吉川（1982）は、動作を表 す動詞の「〜ている」の形は、進行を表すか、結果の持続を表すかは、その動詞の表す事柄のうち、 どの側面を捉えるかにより、主体の動作の側面を捉えた場合が前者、主体の変化の側面を捉えた場 合が後者であると指摘している。

\section{2 動作の繰り返しと経験}

「〜ている」は、動作の進行と持続という意味のほかに、動作の繰り返しと経験という意味も表 すことができる。以下の例をみられたい。

（4）老人のこの話を，彼女はすくなくとも五十回はきいているが，やはりはじめてきくような顔を してきいていた。

(『現代中国文学全集』p.7)

（5）ついに、水泳記録会の日がやって来た。この水泳記録会は、近隣 3 校の合同で行われるため、 他の小学校の子も見ている。

(『五体不満足』p.87)

（4）における「〜ている」は、文字通り動作の繰り返しを表すものであるが、（5）の「〜てい る」は経験または回想のことを意味する。

\section{3 単純状態}

「〜ている」にはまた次のように単純な状態を示す用法もある。

（6）あの人はさびしそうな顔をしている。 (吉川, 1982, p. 66)

（7）ここは北平の普通の横町のように真直か、あるいは、ちょっとばかり曲がっているというので はなくて、まるで酿箪のような形をしている。

(『現代中国文学全集』p.9)

（6）の「〜ている」は、動作の進行などではなく、主体の一種の状態を表すものである。

もそうであるが、（6）とやや違うのは、意味的にある事柄がある状態や性質を帯びていることを表 し、いわば形容詞的用法だというところである。 


\section{3.「〜着」の意味用法の整理}

中国語の「〜着」については、杉村（1994）、守屋（1995）、呂（2003）などの分析がある。以 下、それをもとに「〜着」の意味用法を整理する。

\section{1 動作の進行と持続}

動詞のすぐ後に「〜着」がつくと、動作・行為の進行または動作・行為によって生じた結果が持 続することを表す。また、何らかの動作・状態が持続することを表す。

（8）黄昏的景色在镜后移动着。也就是说, 镜面映现的虚像与镜后的实物好像电影里的叠影一样在 晃动。（鏡の底には夕景色が流れていて、つまり写るものと写す鏡とが、映画の二重写しの ように動くのだった。)

(『雪国 古都 千只鶴』p. 5)

（9）觉慧愤怒地答道, 眼睛里闪着憎恨的光。（覚慧は怒ったような声でいった。眼は憎しみにも えている。)

(『家』p.17)

（8）の「〜着」はどちらかというと動作の進行を表すように思われ、（9）の「〜着」は動作 （状態）の持続を表す。ただ、このような意味上の違いは、ときにあいまいになることが多い。例 えば、「我在宿舍门口等着你们。」（私は寮の入り口であなたたちを待っています。）のように、進 行とも持続ともとれる場合もよく見受けられる（守屋 1995，p. 277）。

\section{2 動作の方式}

前の動詞が後の動作の方式となる場合、前の動詞に「〜着」をつける。一般に単音節動詞に限ら れる。

（10）等到他的轿子转了弯不见了时, 她才捧着她的大肚皮一步一步地走进房去。（彼の轎が角を曲 って見えなくなると、彼女は重いお腹を支えるようにして一歩一歩部屋へもどるのだっ た。)

(『家』p. 390)

（11）瑞宣有时候㜔着祖父来上钱家患门儿, 有时候也独自来。（瑞宣は祖父のお供をして銭家へ世 間話をしにくることもあるが、一人でくることもある。)

(『四世同堂』p. 16)

（10）の「〜着」は、動詞の「捧」（支える）と「走」（もどる）の間に用いられ、「もどる」 という動作の状況や方式を表す。（11）の「〜着」は当文の動詞「陪」と「串门」の間に用いられ、 後者の動作の方式を表す。

\section{4.「〜ている」と「〜着」に共通している用法}

上記の 2.1 と 3.1 にまとめられているように、「〜ている」と「〜着」はいずれも動作の進行と 持続を表す。また、そのいずれにも動作の進行と持続という境界がはっきりしないことがある。こ の 2 点において、「〜ている」と「〜着」が共通している。とはいうものの、その両形式の間に違 いもみられる。 


\section{1 表現機能の差}

日本語における「〜ている」はもっぱらアスペクトの一形式になるが、中国語における「〜着」 はアスペクトの機能をもつ以外に語彙的機能も備わっている。このような語彙的機能に制限されて いるため、中国語の一部の動詞は、「〜着」と一緒に用いることが難しいと思われる。たとえば、 いわゆる瞬間動詞とされる「死」（死ぬ）、「结婚」（結婚する）、「结束」（終わる）、「（房 子 $)$ 倒」（（家が $)$ 倒れる）、「（钱包）掉」（（財布が）落ちる）などには、「〜着」が後接し にくいだろう。この場合、「了」という別のアスペクト助詞でその動作結果の状態を表現する。こ れに対して、日本語では上記の瞬間動詞の後に「〜ている」をつけると、いずれも動作の結果の状 態を表すもので、その結びつきには特に問題はない。

もう一つ「〜着」の語彙的機能にかかわる例であるが、中国語には、次の（12）のように動詞の 後に「〜着」がついていながらも、アスペクトとは関係の比較的薄いようにみえるケースもある。

（12）但是, 两个人好象有一种默契: 你说, 我就听着; 我说, 你就听着。（しかし二人の間には、一 方がしゃべれば一方はきく、という黙契があるかの如くである。）（『四世同堂』p. 16）

(12) の「〜着」は、「〜ていく」のようなアスペクト的ニュアンスを帯びているが、当文におい て主に語調のリズムを整えるために用いられるようにも感じられる。この意味で、ここの「〜着」 はアスペクト的表現形式というより、むしろ機能語的な色彩をもつというほうが妥当かもしれない。 (12) の「听着」に比べ、動詞と「〜着」の結びがいっそう固く、半ば熟語化されるものがある。 手軽に例をあげると、「望着」（眺める）、「随着」（従う）、「留着」（残しておく）、「拉 着」（引っ張る）などたくさん見当たる。この中の「〜着」は、ときにその前の動詞とともに一語 化しており、ときに文脈によってアスペクトの意味を表す。このような表現パターンは、おとらく 日本語の「〜ている」にはないだろう。

\section{2 表現形式の差}

動作の進行を表す場合、日本語では「調べ中」のように「動詞＋中」の形以外に基本的に「〜て いる」の力を借りて表現しなければならないが、中国語では「〜着」のほかに副詞の「在」4で、ま たは文脈的に示されることも多い。次の（13）は文脈的判断で動作進行の意味が捉えられる一例で ある。

(13) 忽然从独院里送出来一阵笛声, 吹的是相思的小调。声音婉转而凄哀, 里面似乎含着无处倾诉 的哀愁。（このときとつぜん中庭から笛の音がもれてきた。吹いているのは恋慕の小唄、そ の音色は婉転極まりなく、訴えるよすがもない哀愁をこめている。）

(『家』p. 301)

「在」と「〜着」の違いについては木村（1982）が詳しい。 
（13）では、「吹」という動詞の後にアスペクトとは基本的に無関係の構造助詞の「的」が用いら れているが、それは当文の文脈から動作の進行、つまり日本語の「〜ている」の意味を表すものと 読み取れる。

一方、動作の結果持続を表す場合、日本語では、「〜ている」のほかに「〜てある」で表現され ることがある。しかし、この二つの形式は、いずれも中国語の「〜着」に対応するため、その区別 は中国語の「〜着」表現にはできないといえる。

\section{5.「〜ている」と「〜着」のどちらかにみられる用法}

\section{1 動作の繰り返しと経験}

前記の 2 と 3 からわかるように、動作の繰り返しと経験を表し得るのは「〜ている」であり、中 国語の「〜着」にはそういう用法がない。

しかし、中国語では動作の繰り返しと経験を表せないかというと、そうでもない。この場合、 「〜着」ではなく、ときにもう一つのアスペクト助詞とされる「〜过」でその意味を表現すること ができる。たとえば、前掲の（4）における「すくなくとも五十回はきいている」のところは、中国 語でいうと「听过不下 50 次」のようになり、「过」と数量詞の「50 次」が用いられることで、動 作の繰り返しという文意が自然に伝わってくる。ただ、中国語では必ずしもすべての場面で「〜 过」の助けを借りて動作の繰り返しと経験を表し得るのではない。もっぱら文脈的意味表現でそれ を描き出すこともあれば、副詞の「经常」（しょっちゅう）や「反复」（反復）のようにほかの表 現形式でその意味機能を果たすこともある。

\section{2 単純状態}

日本語の「〜ている」はまた単純状態の用法をもつ。ここでいう単純状態は、実は二通りの状態 を含む。一つは、前掲（6）のように、場合によって動作結果の状態ともとれるが、実際ある種の状 態を表すものである。もう一つは（7）のように、もつぱら主体の性質という形容詞的意味合いを表 すものである。そのいずれにしてもごく一部のみを除けば、ほとんど基本的に「〜着」に対応しな いと考えられる。

中国語の「〜着」が主体の性質という形容詞的意味用法などをもたないのは、中国語の品詞特徵 によるものと考えられる。たとえば、「弯」という語は、動詞と形容詞の両方の品詞属性をもつ。 よって、アスペクトの場合は「弯着」のような言い方になり得るが、もっぱら主体の性質を表す場 合は「弯」のような言い方になる。これに対して、形容詞的意味の「弯」に近い日本語の「曲が る」は、完璧な動詞であるため、ものの性質を表すには「曲がっている」のように表現しなければ ならなくなるのである。このような違いがあるので、形容詞的用法を表すために、日本語では動詞 


\section{方韻：日本語の「〜ている」と中国語の「〜着」について}

の後に「〜ている」をつける形をとるわけであるが、中国語のほうでは形容詞をそのまま使って表 現するということになる。

\section{3 動作の方式}

これまでのところに示してあるように、動作の方式を表し得るのは中国語の「〜着」であり、日 本語の「〜ている」ではない。これについては次のように考えられる。

日本語では、動作の方式は、たとえば「歩いて行く」のように「〜て」で表すことも可能である し、後項動作展開の状態は前項動詞の後に「〜まま」をつけて表現できる。では、中国語になると どうであろうか。

上記の「歩いて行く」は中国語に訳すと、「走去」と「走着去」という二通りの形式になる。前 者の「走去」はその「走」（歩く）が「去」（行く）という動作の方式を示すというニュアンスが 感じられるが、単に二つの動作をつないでできた形式であるようにも捉えられるだろう。これにひ きかえ、後者の「走着去」というのは、「走去」よりも後項動作展開の方式が「歩いて」だという ニュアンスがずっと強いし、「歩いて」という状況が「行く」動作をずっと伴うという事象持続の 意味合いも多少とも込められている。ここからは、「〜着」は動作方式の意味表現ができ、「〜て いる」にはそれができないということがわかる。

\section{6. おわりに}

本稿では、日本語の「〜ている」と中国語の「〜着」について検討してみた。全体的にみると、 「〜ている」と「〜着」はいずれも動作の進行と持続を表すが、表現機能と表現の形式において違 いがみられる。たとえば、中国語の「〜着」はアスペクトの機能をもつ以外に語彙的機能も備わつ ているため、瞬間動詞とされる「死」（死ぬ）、「结婚」（結婚する）などの語には「〜着」が後 接しにくい。この場合、「了」という別のアスペクト助詞でその動作結果の状態を表現する。これ に対して、日本語では上記の瞬間動詞の後に「〜ている」をつけて動作の結果の状態を表すことは 特に問題がないと思われる。

また、「〜ている」と「〜着」にはそれぞれの用法がある。たとえば、動作の繰り返しや経験な どは、日本語の「〜ている」では表し得るが、中国語の「〜着」にはそういう用法がない。一方、 動作の方式になると、中国語の「〜着」で表し得るが、日本語の「〜ている」ではできない。

以上の考察結果を表でまとめると、次のようになる。 
「〜ている」と「〜着」に関する意味用法の比較

\begin{tabular}{|l|c|c|}
\hline & $\sim$ ている & 〜着 \\
\hline 動作の進行・持続 & $\bigcirc$ & $\bigcirc$ \\
\hline 動作の繰り返しと経験 & $\bigcirc$ & $\times$ \\
\hline 単純状態 & $\bigcirc$ & $\triangle$ \\
\hline 動作の方式 & $\times$ & $\bigcirc$ \\
\hline
\end{tabular}

（注： $\bigcirc=$ 可; $\times=$ 不可 ; $\triangle=$ 基本的に不可）

\section{用例出典}

-巴金（作）、飯塚朗（訳）（1956）『家（下）』東京：岩波書店；巴金（1962）『家』（第 2 版）北京：人民文学出版社

・司馬遼太郎（1989）『アメリカ素描』東京：新潮社

・老舎（作）、鈴木択郎（ほか）（訳）（1954）『現代中国文学全集第四巻 老舎篇』東京：河出 書房； 老舍（1998）『四世同堂』北京：北京出版社・北京十月文艺出版社

•乙武洋匡（1998）『五体不満足』東京：講談社

・村上春樹（1985）『羊をめぐる冒険（上）』東京：講談社

• 川端康成（作）、叶渭渠・唐月梅（訳）（1999）『雪国・古都・千只鶴』南京：译林出版社

•川端康成（1971）『掌の小説』東京：新潮社

\section{参考文献}

- 庵功雄（著）、于日平（ほか）（訳）（2005）『新日本语学入门：考察语言的结构』北京：外語 教学与研究出版社

・加藤泰彦・福地務（1989）『外国人のための日本語例文・問題シリーズ 15 テンス・アスペクト・ ムード』東京：荒竹出版

・ 木村英樹（1982）「テンス・アスペクトー中国語」『講座日本語学 第 11 巻』東京：明治書院

・ 申泰海・赵基天・王笑峰（1991）『詳解日語語法辞典』長春：吉林教育出版社

• 杉村博文（1994）『中国語文法教室』東京：大修館書店

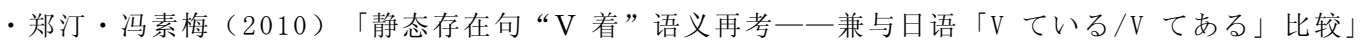

『日语学习与研究』北京：日语学习与研究杂志社

・寺村秀夫（1984）『日本語のシンタクスと意味 第 II 巻』東京：くろしお出版 
方韻：日本語の「〜ている」と中国語の「〜着」について

-马园园 (2010)「「ている」和「着」的对比研究」哈尔滨: 『林区教学』编辑部

・守屋宏則（1995）『やさしくくわしい中国語文法の基礎』東京：東方書店

・吉川武時（1982）「日本語教育におけるテンス・アスペクトのあつかい」『日本語学』東京：明 治書院

- 李所成（2009）「试论「ている」的性质及意义」『日语学习与研究』北京：日语学习与研究杂志 社

- 呂叔湘（編）、牛島徳次 - 菱沼透（監訳）（2003）『中国語文法用例辞典』東京：東方書店 